\title{
The View from Next Door: Greek-Turkish Relations after the Coup Attempt in Turkey
}

Nikos Christofis ${ }^{\mathrm{a}}$, Bahar Baser ${ }^{\mathrm{b}}$, and Ahmet Erdi Öztürk ${ }^{\mathrm{c}}$

${ }^{\mathrm{a}}$ Shaanxi Normal University (SNNU), ${ }^{\mathrm{b}}$ Coventry University and Stellenbosch University, ${ }^{c}$ Linköping University

Contact: Nikos Christofis, Email: n.christofis@gmail.com Twitter:

https://twitter.com/ChristofisN

\begin{abstract}
Turkey's recent slide into authoritarianism will have implications for its close neighbours in the West. Especially Greece cannot avoid negative spill-over effects. A coalition government comprising Syriza and Independent Greeks does not have an unconstrained set of policy choices in responding to this. Maintaining effective working relations is a paramount interest but achieving this is easier in principle than in practice especially considering the issues of asylum seekers and Turkish revisionism on the Lausanne Treaty. Unlike the two parties that dominated the Greek political scene after 1974, PASOK and New Democracy, the current government has little experience navigating choppy diplomatic seas with Turkey.
\end{abstract}

Keywords: Greece, Turkey, authoritarianism, SYRIZA, AKP, New Democracy 
The implications for accession to the European Union (EU) notwithstanding, observers of Turkey's current period of political instability have paid scant attention to the constraints and opportunities that will shape the policy response of close neighbours, Greece in particular. This is puzzling, given that the July 2016 coup attempt, the subsequent purges and crackdown on dissent, and the sanctioning of a powerful executive presidency alla Turca in the April 2017 referendum pose very real challenges for policymakers in neighbouring states and the Mediterranean region more generally (Tziampiris 2016).

Once seen by European actors as the answer to Turkey's long-standing 'reformist deficit', today the ruling AKP (Adalet ve Kalkınma Partisi/ Justice and Development Party) has increasingly turned to undemocratic measures to cling to power (Baser and Öztürk 2017). Most were willing at first to turn a blind eye to this shift but after the 2007 elections, criticism and rebukes from Turkey's European partners increased noticeably. Some in the press (Tisdall 2018) and Europe's political class went so far as to label Turkey a dictatorship in the making. Given the fluid context, to date little scholarly consensus has emerged regarding the precise bearing that Turkey's new political configuration will have on its Western neighbours.

Although some argue that Turkey's political turmoil will eventually bring negative spill-over effects for Greece, others have interpreted instability in Turkey as good news. For instance, Konstandaras (2016) has argued, rather optimistically, that Greece will emerge as a kind of strategic anchor of stability in the region, opening up the prospect of negotiating a new deal for support and debt relief from the EU. He claims Greece has and will continue to benefit from the tourism share that Turkey has ceded in recent years. Others such as Roussanoglou (2017) believe Greece is well-positioned to capture the lion's share of 'capital flight' from Turkey if current conditions worsen. Roussanoglou's report (2017) that increasing numbers of Turkish citizens are acquiring property in Greece underscores this point.

Irrespective of whether these positives transpire, Greece cannot escape the fact that the refugee/migration issue will continue to pose a monumental challenge. The potential influx of yet more refugees from Syria, but also from Africa and the Middle East (and even Turks themselves), looms on the horizon - in case of collapse of the Turkey-EU refugee deal bringing devastating effects upon Greece (Bilgic and Pace 2017; Bialasiewicz and Maessen 2018), while Turkey's discursive revival of historic disputes such as Lausanne hangs like a 
sword of Damocles over its head. Therefore, Greece needs to keep a delicate balance between Turkey and its commitment to democratic values and human rights.

Studying relations between the two countries became all the more interesting when President Recep Tayyip Erdoğan visited Greece in early December 2017, the first Turkish president to do so in 65 years. The meeting was nevertheless not free from tensions; as the The New York Times (Kitsantonis and Gall 2017) put it, it turned into a verbal theatre of war when Erdoğan crossed an array of red lines. Turkish policymakers had already been mentioning their discontent with the Lausanne Treaty for a while, however remarks regarding discussion of the treaty became all the more frequent after the 2016 coup attempt in Turkey, when Greece started receiving a high number of asylum seekers from Turkey, some of whom had allegedly taken part in the putsch. Thus, the meeting between Erdoğan and Greek Prime Minister Alexis Tsipras was turned into a platform where the dormant tensions between the two countries were revived.

In this article, we analyse the impact of Turkey's "exit from democracy" (Akkoyunlu and Öktem 2016), and/or “Erdoğan's majoritarian drift” (Özbudun 2014) on Greek politics and in particular its foreign policy towards Turkey. We argue that Greece cannot avoid a number of negative spill-over effects that will require careful manoeuvring on the part of policymakers in Athens.

First, the regime in Turkey is becoming more authoritarian and politics is increasingly informed by a public discourse that is less secular, less EU-oriented and more Islamicconservative and nationalist, at least in tone, if not in practice (Esen and Gumuscu 2016). Beyond that, as Çınar (2018) notes, the AKP regime, under the leadership of Erdoğan, has been trying to redefine the Turkish state identity and this redefinition process has been feeding on authoritarian practices. The coalition government in Athens comprising Syriza (Synaspismós Rizospastikís Aristerás/Coalition of the Radical Left) - a radical-leftist-turnedpopulist party - and Independent Greeks (Anexartitoi Ellines, Anel), a populist radical rightwing party, does not have an unlimited or unconstrained set of policy choices in responding to this. Maintaining effective working relations is a paramount interest for Greece but achieving this is easier in principle than in practice. It is necessary to understand what options a coalition government of leftists and nationalists in Greece has in maintaining effective working relations with an increasingly undemocratic neighbour. 
Second, many educated, upper middle class Turkish citizens are fleeing Turkey (or contemplating to do so) due to fears their politics or lifestyle makes them a target of the state. Some have sought asylum in Greece; others are seeking to receive a golden visa through the purchase of property. This means that there is a Turkish diaspora in the making in Greece. Third, the thorny issue of Turkish military officers who were part of the coup attempt seeking political asylum in Greece will continue to strain Turkish-Greek relations for some time. And finally, Greece is the pivot point for the EU-Turkey refugee deal and any major shift in the agreed arrangement will impact Greece profoundly as it will have no choice but to adapt (Tziampiris 2016). Unlike the two parties that dominated the Greek political scene after 1974, PASOK (Panellinio Sosialistiko Kinima/Panhellenic Socialist Movement) and New Democracy (Nea Dimokratia, ND), the current government is not that experienced in navigating choppy diplomatic seas with Turkey. Therefore, the unfolding events will indisputably put the left-wing Syriza party's commitment to human rights and leftist principles to the test.

This article therefore contributes to the empirical literature on Greek-Turkish relations with a specific focus on the period that marks the democratic decline in Turkey. It aims to put emphasis on the Greek perspective on contemporary Turkish-Greek politics and to scrutinize how Greece reacts to this remarkable transformation period in Turkey. To lay out the context, the article begins with a brief survey of Turkey's domestic politics and developments since the July 2016 coup attempt. It then focuses closely on the current structure of Greek domestic politics, detailing the factors that have shaped the position of Syriza (and to a lesser extent, that of its coalition partner, Anel) on Turkey's domestic issues. The following section draws out some key implications of that analysis for Greek-Turkish diplomatic relations in the near term. It does so through the prism of two 'hot' issues: Turkish asylum seekers and Turkey's revisionism regarding the Lausanne issue.

\section{A synopsis of Turkey's authoritarian turn}

Since 2002, Turkey has been governed by a single-party government, an unparalleled development for a political system historically characterised by a weak and fragmented party system and long periods of unstable coalition government (Özbudun 2014). Since 2007 especially, the ruling AKP and its indisputable leader, the current president, Erdoğan, have emerged as the most successful political actors in modern Turkish history. While initial high 
hopes for democratic consolidation in Turkey were placed in Erdoğan (İnsel 2003), it is now abundantly clear that he and the party he leads have joined Hungary's Viktor Orbán and Fidesz (Fiatal Demokraták Szövetsége/Alliance of Young Democrats) and Russia's Vladimir Putin and United Russia (Yedinaya Rossiya) in the early $21^{\text {st }}$ century club of right-wing, nationalist-populist regimes.

Erdoğan has achieved this dubious honour largely by instrumentalizing successive political crises in Turkey (Akkoyunlu and Öktem 2016), including the bloody putsch on 15 July 2016. Five days after the coup attempt, the AKP government declared a three-month state of emergency, which was extended without interruption for two years. Under the cover of this state of emergency, Erdoğan and the AKP pursued a program of purges and a media clamp down intended to stifle opposition and reinforce the ruling party's hegemony. The post-coup process then turned into a purge in massive scale by which all state institutions have gradually been 'cleansed' of dissident voices against the ruling party, most of whom belonged to the Gülen Movement.

It is essential to know the complicated relationship between the Gülen Movement and the AKP to understand both Turkey's authoritarian turn and the July 2016 coup attempt. Even though the Gülen Movement defines itself as an education-oriented transnational faith based on inter-cultural and inter-religious dialogue, it also has para-political branches in the Turkish media, business networks and state structure which have always aimed to break the hegemonic role of Turkey's historic Kemalist-secular establishment. Given this common objective, the Gülen Movement and the AKP created an informal coalition and together eliminated most of Turkey's establishment between 2007 and 2013. After that, however, they found themselves in a power and interest-based conflict as to who would be the decisionmaker regarding the future and identity of the Turkish state.

In this regard, while the AKP started to terrorise the Movement and banned its institutions and associations, the Movement tried to demonstrate that the AKP is an illegitimate and corrupt political structure by using its national and international media power and human capital within the Turkish bureaucracy, legal system and police structures. As a result, the AKP increased its authoritarian practices towards all opposition groups with the justification of defending the country against the 'enemies of the state'. The coup attempt was the last drop in this process since the Gülen Movement, or at least some of its important elements and 
members were involved in it (Watmough and Öztürk 2018). Yet, the rulers of the 'new Turkey' have preferred not to punish solely the perpetrators of the putsch. Instead, they have instrumentalised the coup atmosphere to purge almost all members of the Gülen Movement and the most significant opposition groups, such as secular academics, Kurds and human right activists in the Turkish socio-political arena.

As Milan $(2016,28)$ put it, "While the coup in itself was indeed a blow to Turkey's democratic credentials, Erdoğan's response also unequivocally failed the democracy test". The judiciary has been tamed and the opposition parties have either been marginalised (CHP - Cumhuriyet Halk Partisi/Republican People's Party), co-opted (MHP - Milliyetçi Hareket Partisi/Nationalist Movement Party) or targeted (HDP - Halkların Demokratik Partisi/Peoples' Democratic Party). Indeed, the co-chairs of the pro-Kurdish HDP remain in prison awaiting an uncertain fate. Municipal governors of many Kurdish-majority cities and districts have also been arrested and their posts filled by pro-government administrators.

Most significantly of all, the crisis and the state of emergency presented Erdoğan with the opportunity fundamentally to reorder the political system to his benefit, in a manner perhaps unprecedented in the Turkish Republic's near 100-year history. Seizing the moment of crisis to advance his long-term vision of replacing Turkey's parliamentary system with an executive presidency with virtually untrammelled power, Erdoğan has championed fundamental revisions to the constitutions. According to the new constitution, the President has the ability to re-design all the ministries, public institutions and state apparatuses by issuing a simple presidential decree. Therefore, with the new form of the constitution, the Presidential decrees have become one of the fundamental norms of the new regime. Despite allegations of serious vote rigging, blunders by the High Election Council and strong evidence of undemocratic practices in the run-up to the vote, the changes President Erdoğan sought were narrowly approved by the voters in the April 2017 referendum_(Öztürk and Gözaydın 2017).

Under these circumstances, many Turkish citizens, primarily secular Turks, Kurds, Alevis, and Gülenists are fleeing or migrating to Greece and other European countries. Some are applying for asylum while others are buying property to obtain residence permits. ${ }^{1}$ According

\footnotetext{
${ }^{1}$ This data is based on statistics released by the Bank of Greece (BOG), cited in Grekodom.com 2017.
} 
to official Greek reports, after the coup attempt in Turkey more than 5000 Turkish citizens applied for asylum in Greece (sputniknews.com 2018). Most of the asylum seekers are either members or are accused of being members of the Gülen Movement, held responsible for plotting the coup attempt (Weise 2018).

White collar Turkish citizens are also leaving Turkey. As Baser and Korkmaz put it:

Many people in the opposition think the rule of law is being eroded, that elections are not fair, that secularism is being replaced by a creeping Islamism (especially in the education sector), and that their lifestyles are in danger. As long as this disaffection persists, more emigration from Turkey to the West seems inevitable. And if the result is a steady outflow of privileged, educated citizens, it might cause a significant brain drain, with severe long-term consequences for Turkey's society and economy.

In 2017 , around 3000 visa applications were made to the UK to benefit from the special agreement for Turkish entrepreneurs between the UK and Turkey called the Ankara Agreement (migrantsrights.org 2018). More than 3000 Turks also filed asylum applications in Germany in the same year (DW.com. 2018). Although it seems like Greece is not the first choice for Turkish migrants, it still is one of the Western countries receiving recent waves of Turkish migration for a variety of reasons including cultural and geographical proximity as well as golden visa opportunities (Immigration.ca n.d). This means that apart from concerns for Greece at the diplomatic level, Turkey's domestic issues will certainly spill-over to Greece via migration flows as well.

The political transformation at home has led to a new foreign policy course that has resulted in the reconfiguration of attitudes in policymaking circles. Of great importance is the European Union's stance on Turkey's membership process and the efforts made by the AKP in its first term in power, which the Turkish government regards as insincere. This has led to a distancing between the two. Furthermore, the AKP's 'geographic imagination', closely linked to developments before and after the Arab uprisings, includes neighbouring countries such as Greece, and should be considered part of the 'normalisation' of Turkish politics and the identity the AKP is trying to construct (Christofis 2018b, 134-135). In the next section, we take a close look at the Greek approach to these recent transformations in Turkey.

\section{Greek politics in transition}


Greek-Turkish relations has always been predominantly "a history of obsessive symbolic and pragmatic tensions, a history of repeated and enduring enmity" (Karakatsanis 2014, xi). Issues such as Cyprus, or the Imia/Kardak islands, have returned to the political scene with full force after a tension-free period in relations between the two countries during the first, more liberal period of AKP rule. The current moment of crisis and instability in Turkey has had both direct and indirect impacts on Greece, and all have been exacerbated by international developments in the West and the Middle East, but also by the domestic, mainly economic, crisis in Greece. Present-day conditions mark a new era in the relations of the two countries, an era that is still 'in progress'.

Most relevant to our discussion here is that the present Turkish crisis has put the Greek coalition government, especially the left-leaning Syriza, in a difficult position. The two parties that comprise the current coalition face different constraints and incentives regarding Turkish issues and this messy political reality makes navigating the current instability even more difficult than it would ordinarily be for an administration that has only just managed to find its feet in the wake of the Greek government debt crisis.

Syriza's fortunes shifted dramatically in 2009 in the wake of the financial crisis. The party's uncompromising stance on conditionality and the memoranda brought an air of optimism to Greek society, after an unstable period in which the older parties seemed unable to act in the national interest (Christofis 2014, 49). The crisis reached a peak in Greece in 2010, when the first Memorandum of Understanding (MoU) was signed, marking at the same time a crack in the coalition government formed by the right-wing ND, PASOK, and the centre-left DIMAR (Dimokratiki Aristera/Democratic Left). In the January 2015 elections, Syriza's vote share vaulted to 36.3 percent, and it formed a coalition government with the Anel, the populist radical right spinoff from ND. ${ }^{2}$ Fresh elections held in September of the same year produced the same result: Syriza took 35.5 percent of the vote and its coalition government with Anel continued (Aslanidis and Lefkofridi 2013, 28).

By claiming ownership of the issue gaps left by the major parties (Norris 2005, 6-7), and zeroing in on other factors (Spourdalakis 2016) - notably, the economic crisis (Ovenden 2015) - the Party of the Left claimed 149 seats in the elections. The party consistently countered the 'TINA' (There Is No Alternative) orthodoxy by arguing that austerity could be

\footnotetext{
${ }^{2}$ Born a couple of months before the 2012 election, Anel managed to garner an impressive 10.6 percent of the votes. Despite a decline to 7.51 percent in the follow-up June election, the wound Anel inflicted on ND's right flank is still draining the lifeblood out of the former bastion of the centre-right (Aslanidis and Lefkofridi 2013).
} 
fought from within the euro area, a position that signified a rupture with the corrupt political elite and its party-oligarchy comprising PASOK and ND.

While seeking to take a broad brush to the corrupt status quo at home, Syriza's position on most foreign policy questions was both moderate and EU-centred. Comprising members from across the spectrum of the Left, the party is staunch believer in the EU. Its pre-election policy position made this point clearly: "Syriza is not a force of Euroscepticism and rejects the rise of nationalism as a response to the policies of the EU" (Syriza 2015; Tziampiris 2017).

The party opposed the so-called Grexit scenario. In particular, following the 5 July 2015 referendum in Greece, Tsipras rejected the 'in or out' dilemma, and stated: 'Greece is, and will remain an indispensable part of Europe, and Europe, an indispensable part of Greece. But Greece without democracy is a Europe without identity or a compass" (Michalopoulos 2015). The way in which Syriza's campaigning and electoral victory threw into sharp relief the much broader debates about the direction of the European project triggered by the crisis is captured by Mazower (2015): “Syriza's [January 2015] victory stood not for a repudiation of Europe, but for a redefinition of it."

Having campaigned in poetry, the challenge of governing in prose meant that Syriza had to make tough choices. Despite its electoral triumph, Syriza was left with a limited range of options as the party was bound not to join the 'pro-Memoranda' bloc. At the outset, the KKE (Kommounistikó Kómma Elládas/Communist Party of Greece) rejected any coalition proposal from Syriza, leaving it two choices: Anel and To Potami (The River). The latter was formed in 2014 in response to the crisis, but it championed reform and its take on the memoranda was ambiguous, so Syriza chose Anel as a governing partner instead.

For its part, Anel has been very adaptive in this new partnership with Syriza and effectively prevented occasional misunderstandings from ruining the partnership, which is however not without obstacles. While, for example, Anel were not comfortable with the 'open borders' outlook on the refugee question advocated by various Syriza affiliates, they did not protest openly. Instead, the party called for Migration Policy Minister Ioannis Mouzalas's resignation because of his reference to Greece's northern neighbour as 'Macedonia' rather than 'the Former Yugoslav Republic of Macedonia/FYROM', an issue that has been brought up again more recently and has once again plunged relations between the two parties into 
murky waters. ${ }^{3}$ Furthermore, Anel has taken the recent Turkish instability as cause to publicly rebuke the country as a constant threat to its neighbours. While Greeks no doubt are generally in agreement, the party's aggressive, xenophobic rhetoric sometimes puts Syriza in a tight spot. Syriza does not govern alone, and as such, aligning party rhetoric with government rhetoric and diplomatic practice has proven a challenge. Nevertheless, as Petsinis (2017) rightly comments, "Anel have turned out to be very efficient in inventing ways to maintain the status quo with Syriza."

\section{Syriza's foreign policy}

Syriza has traditionally hewed to a political vision that stresses Marxist ideology and antiimperialism, especially on questions of global political economy and geopolitics. The party platform had always championed Greece leaving NATO (eschewing military alliances in general) so as to avoid foreign military entanglements in the pursuit of an independent, peaceful foreign policy (Synaspismos 2009). When Nikos Kotzias, a qualified and experienced diplomat and professor of international relations, was appointed as foreign minister, it "led immediately to sensationalist, Cold War headlines about Athens going over to Moscow" (Ovenden 2015). Yet, the Syriza-Anel coalition has not moved over to the 'Moscow axis'. On the contrary, it has demonstrated a 'mainstream' foreign policy on some issues, resembling partly that of its predecessors, while on others, such as its opposition to sanctions against Russia regarding Crimea (Walker 2015), or China on human rights (Emmott and Koutantou 2017), it seems to have broken away from the mainstream, while adopting a rhetorical stance in relation to matters that match its commitment to fiscal prudence (Neuger and Chrepa 2015).

In that respect, Kotzias presents no radical ideology; his policy orientation has always been realist and pragmatic, with a very orthodox reading of Greek foreign policy doctrine (Christofis and Logotheti 2018) particularly regarding the Middle East and the eastern Mediterranean. His public comments soon after taking office demonstrate this continuity in Greek state policy (Cfr Ker-Lindsey 2007). He stressed Greece's geopolitical importance in the Balkans and the Mediterranean, yet warned that " $[t]$ here will be millions of migrants and thousands of jihadists flocking into Europe if the Greek economy crumbles" (Chrysopoulos

\footnotetext{
${ }^{3}$ In October 2018, the 'Macedonian question' led once again to friction, this time between Foreign Minister Kotzias (Syriza) and Defence Minister Panos Kammenos (Anel), and resulted in the former's resignation. Tsipras' support for Kammenos shows, at least to these authors, that political cost and pragmatism come before ideological agendas, as the resignation of Kammenos would have led to early elections and, probably, to Syriza losing the elections (Strickland 2018).
} 
2015). In the party's analysis, Greece had become a 'colony of debt'. Before coming to office, Kotzias himself had stressed the imperative to shift the status quo fundamentally:

Having the country getting rid of the memoranda constitutes a prerequisite for a new foreign policy, multidimensional and proactive, which will protect the interests of the Greek people. And the other way 'round, a foreign policy that will give again to the country its own voice in international matters, is necessary for the country and people to get rid of a colony of debt regime (Tziampiris 2017, 262).

This ultimate objective of this approach was the restoration of Greek national sovereignty through a final settlement with Greece's creditors that would completely overturn the status quo. Such an agreement would acknowledge the social ills caused by austerity, foster progrowth policies and deal realistically with Greece's ruinous and seemingly unsustainable debt burden (Tziampiris 2017, 262).

Syriza's foreign policy goals were characterized by a reformist zeal and were arguably motivated by an idealism that right would eventually trump might. But since 2009, crisis has sucked virtually all other oxygen out of the room, leaving governments no alternative but to focus almost exclusively on economic management and recovery. The Syriza-led government is no exception. In his famous campaign speech in Thessaloniki - the so-called 'Thessaloniki Manifesto' that led to Syriza's January 2015 electoral triumph - Tsipras devoted literally one line to foreign policy:

Only with an active and multidimensional foreign policy will [Greece] be able to safeguard its interests, leaving behind both the role of the docile student and the 'agent' of Germany's interests, a role that happily Samaras and Venizelos took over (Tsipras' Speech 2014).

A foreign policy agenda was published shortly after Syriza assumed power but it clearly showed the limits the new government faced. The policy effectively held "the government hostage [to] a national interest that allows strategic manoeuvres but not radical deviations from a carefully designed eternal national plan neither apt nor proper to redefine" (Christofis and Logotheti 2018). A fundamental divide between rhetoric and practice thus opened up: the latter was driven by the traditional motivations and ideological grounding of the party, the latter by the insuperable weight of "the national interest" (Christofis and Logotheti 2018, 107). 
Syriza's foreign policy has thus been fundamentally structured by the dictates of economic policy in the context of rolling crises. More specifically, as Tziampiris asserts, Greek foreign policy has had to pursue three objectives simultaneously: 1) seek the best possible outcome in anti-austerity negotiations, partly by reminding creditor nations of the geopolitical importance of Greek stability in a turbulent region and of the country's existing institutional powers within the EU; 2) lay out available alternative contingencies in the event of an involuntary and abrupt Greek exit from the Eurozone; and 3) contribute to a new multifaceted diplomacy involving an extended range of states and international partners (Tziampiris 2017, 263).

The most compelling explanation for Syriza's apparent change of heart is therefore the simple logic that, on coming to power, the demands of governance naturally tend to tame the more 'radical' elements of political parties of either persuasion. Of course, at the rhetorical level both Syriza and Anel have maintained their respective ideological-rhetorical stances, especially at party congresses and other intra-party meetings. As a matter of public administration, however, practice has clearly reflected the need to stabilise the system and set the country on the path to recovery. Within Syriza, the politics of crisis has meant that the voices of reason and prudence have prevailed, excluding at the same time the moderate, antinationalist fractions (Heraclides 2017).

\section{Turkey in Syriza's rhetoric}

Recent conditions present new terrain for the Greek coalition government, and perhaps more for the Syriza party. In opposition, Syriza could criticize government decisions without cost. A case in point was the period during the Gezi protests in Istanbul in 2013, which many party members presented as "an uprising for democracy, freedom and dignity" in the face of Erdoğan's program of "barbaric neoliberal development and competitiveness" (NewsBeast 2013).

The picture changed drastically, however, once Syriza came to power. The most revealing example of this was during the Turkish general elections of June 2015, the results of which posed new challenges for the Greek government. For the first time, the Turkish elections marked the entrance of a pro-Kurdish, leftist party - the HDP, which took 13 percent of the vote - in the Turkish Grand National Assembly (Tekdemir 2016). Before this date, proKurdish parties had participated in elections with independent candidates in order not to risk not passing the 10 percent threshold. The Turkish government responded with a criminalising 
discourse against the HDP, accusing them of supporting terrorism, which caused uneasiness in Syriza.

As Tekdemir $(2016,6)$ explains, the AKP and HDP compete for hegemony over the Kurdish population, especially in Southern Turkey:

The HDP's left-leaning (inclusive, pluralist and emancipatory) populism can be contrasted with the AKP's right-wing (exclusive, monist and authoritarian) populist articulation and is clearly distinguishable by the nature of their definitions of 'the People' (citizenship), democracy and secularism, although they share similarities in the way they deploy the core concepts of populism to achieve hegemony.

Therefore, it can be argued that the once political partners during the peace process in Turkey were in competition to receive Kurdish votes. HDP's presence in the Turkish Parliament posed a significant problem for the AKP to reach the number of seats needed to form a majority government. As O’Connor and Baser $(2018,60)$ put it:

Considering that one of the HDP's election campaign slogans was 'We will not make you the President!' (referring to Erdoğan), it is obvious that the elections were seen as critical for constitutional change in Turkey. Therefore, the competition was not solely for seats but rather the power to fundamentally restructure Turkey's political institutions.

After the collapse of the peace process in 2015, the AKP's discourse towards the HDP started to change drastically from that of a conventional ally to constantly accusing the HDP for having organic links with the PKK (Kurdistan Workers Party).

The close ties between the Greek Left and the Kurdish movement go way back, without however being free from frictions and tensions, as with the Abdullah Öcalan case (Karakatsanis 2014, 105-135). Good relations were evident in the exchange of visits and letters of support, something that continued with the HDP during the Syriza-led government. For example, on 23 May 2015, Yiannis Bournous, a member of the political committee of the party, represented Syriza at an HDP election rally in Izmir, a visit that led to the arrest of seven HDP members. ${ }^{4}$ Bournous had expressed Syriza's support for the HDP, and called for solidarity with oppressed peoples to protect the region from chauvinist and extremist tendencies (Avgi 2015).

\footnotetext{
${ }^{4}$ Interview with Yiannis Bournous by Nikos Christofis and Amaryllis Logotheti, Athens, Greece, 23 November 2016.
} 
Soon after, HDP co-leader Selahattin Demirtaş returned the favour and, during an unofficial visit to Athens, thanked the Greek prime minister for his support of the HDP (Left.gr 2016a). In October of the same year, Syriza officially invited its fellow traveller on the Left to participate as an observer in the party's second congress. This clearly signalled that Syriza considers the HDP a progressive, democratic and leftist force in the world on a par with itself (Left.gr 2016b).

The extreme violence against the Kurds, and the imprisonment of most of the Kurdish leaders in the following months, led to a series of statements by the Greek left parties, including Syriza, criticizing AKP policies. A large demonstration was held in the Syntagma square in solidarity with the Kurdish people (Left.gr 2016c). On the other hand, the Greek government refrained from issuing a statement condemning the alleged accusations against the Kurdish leaders. This came as no surprise as other countries had also refrained from officially taking a stance against the illiberal policies of the AKP. Such an act would rightly be considered an interference in the domestic affairs of a foreign country, with severe repercussions on diplomatic relations. This silence, however, allowed Erdoğan to crack down on Turkish political institutions, civil society and academia with impunity "because European leaders were unable to face their own demons of racism, Islamophobia, human rights violations and sheer egotism" (Benhabib 2017). This did not remain unnoticed by the Greek left. Another case in point is the conclusion of the agreement on migration between Turkey and the EU on 18 March 2016; both countries presented the agreement as a panacea for Europe's migrant crisis (European Council 2016).

The steady repression by the Turkish authorities and government targeting the Kurds seems to have had some effect on Syriza's approach. The party - and the entire coalition government for that matter - has noticeably reduced the frequency of public statements of support for the HDP and relations appear to have cooled, at least on the face of it. Arguably this may be a carefully played policy by the Greek government to avoid antagonizing the Turkish government and creating further tensions between the two countries. Nevertheless, considering the case of the eight Turkish officers and other issues, Kotzias' rather impolitic statement that "the Kurds should have those rights that the Republic of Cyprus intends to give to the Turkish Cypriot community" (HellasJournal 2017) could easily have caused friction and tension in relations between the two countries.

\section{Implications: Turkish-Greek relations in the new situation}


Drawing on the foregoing analysis, we can now sketch out some of the implications for future Greek-Turkish relations, focusing particularly on the issues of asylum seekers and recent Turkish revisionism on the Lausanne issue.

Greek-Turkish relations have always been somewhat fragile. Historical enmity is a factor, but the circumstances at the foundation of the Turkish Republic have provided much of the animus between the two countries over the past 100 years or so. As Couloumbis and Kentikelenis $(2007,517)$ wrote, "for long, the Greek-Turkish space had been characterized as a volcanic zone that was expected to erupt into generalized warfare at anytime, anywhere between the Aegean and Cyprus". The Turkish invasion of Cyprus in 1974 or alleged Greek support for the PKK deteriorated relations between the two countries (Couloumbis and Kentikelenis 2007). At the end of the 1990s, however, the so-called "earthquake diplomacy" (Carkoglu and Kirisci 2004) in the wake of the 1999 disaster in Turkey brought the erstwhile adversaries together, starting a period of normalisation that has continued without any actual confrontation between the two countries since then. Diplomacy has focused mainly on issues of 'low politics' rather than 'high politics', keeping essential and crucial issues that have been haunting bilateral relations for decades off the agenda (Raptopoulos 2017, 120). At the same time, Turkey's foreign policy problems with Greece have lost their priority on the Turkish political agenda as the conflicts in the Middle East have occupied Turkish policymakers during the last decade. ${ }^{5}$ Even though, relations continue to be marred in the Aegean, especially as concerns air space. Dogfights and other tensions still occur and sometimes have the potential to escalate depending on the domestic and foreign policy priorities of the two countries (Larrabee 2012, 473).

Indeed, recent developments demonstrate that, during times of crisis, old enmities and disputes have a way of resurfacing and familiar tensions are simply reframed in terms of the latest context. Immediately after the coup attempt, Tziampiris (2016) warned that "Greece now has a neighbour that is more divided, isolated and weak. The last thing that Athens should do is provide an excuse to Ankara to turn its domestic challenges into a dispute with Greece". In his opinion, it was the Kemalist elites that had kept Turkish-Greek relations in a poor state for many years; Islamists, therefore, might have a different approach.

\footnotetext{
${ }^{5} \mathrm{~A}$ full account is not possible, however it should be noted that Turkey's foreign policy agenda has prioritised issues related to Syria, Israel-Palestine and Iraq during the AKP period. For more information, see Tezcur and Grigorescu 2014.
} 
However, the aftermath of the putsch has shown that Turkish ruling elites are compelled to act in a certain way to galvanize nationalist feelings and give the impression both to the outside world and to its own supporters that Turkey is still strong. Furthermore, the Turkish government was angered by the fact that Greece did not cooperate regarding the deportation of military personnel who had allegedly taken part in the coup attempt in Turkey and subsequently sought political asylum in Greece. This issue then led to other crises, such as the Lausanne debate and the Kardak issue as will be detailed below.

\section{The case of the Eight}

No sooner had the coup been put down, than the Greek government found itself caught up in a thorny political issue that rekindled mutual mistrust between the two countries. On the morning of 16 July 2016, eight Turkish military personnel fled to Greece by means of a military helicopter - which had been used during the coup attempt itself - and immediately sought political asylum. Once the actions of the officers were revealed, Turkey's foreign minister, Mevlüt Çavuşoğlu, immediately requested that Athens return them to Turkey to face justice. A Greek government spokeswoman announced that the helicopter would be returned right away but that the officers' asylum claims would have to proceed according to international law. In a somewhat bizarre turn of events, a Greek court then handed down a two-month suspended prison sentence to the eight military personnel for illegal entry into the country. In the midst of all the tension and exchange of official statements between the Greek and Turkish governments, Erdoğan openly mulled over reinstating the death penalty, an issue that bears directly on the refugee status of the eight soldiers concerned. Under Greek or international law, the existence of the threat of a death penalty for an asylum seeker in their homeland might further complicate how asylum cases are being handled.

With Turkey's demand that 'the eight', as they came to be known, be extradited, the Greek government was handed a ticking political bomb. The Greek administration, however, did not miss a beat and Deputy Foreign Minister, Yiannis Amanatidis, issued a statement assuring all interested parties that the case of the eight would be fast-tracked, but repeating that the Greek government's stance was that the case must proceed according to Greek and international law. As Triantaphyllou (2017) wrote;

The decision of the Greek Supreme Court to deny the extradition of 8 military officers that sought refuge in Greece after the 15 July 2016 coup attempt in Turkey not only brought about the ire of Turkey with possible negative consequences in bilateral 
relations; it also had the support of a vocal segment of Greek civil society that took a public stand against the extradition on human rights grounds.

Çavuşoğlu stated that Greece had already agreed to extradite these men, a claim that his Greek counterpart, Kotzias, publicly refuted. At the same time, Tsipras phoned Erdoğan to confirm that the Greek side would do 'whatever necessary' to ensure the extradition of the eight. In another phone call with Prime Minister Binali Y1ldırım, Tsipras said that Greek authorities had already commenced the extradition process and later he reassured the Turkish authorities that "there was no room for coups in democracies, and the Greek government stood by and respected the elected government of Turkey and the will of the Turkish nation" (Daily Sabah 2016).

The same opinion was expressed by Kotzias in one of his rare interviews:

Politically, we condemn any type of coup, and we would be the last country and especially the Greek Left - that could accept or tolerate a military coup. On the other hand, who is or isn't a putschist - and whether he has or will have a fair trial in Turkey or not and has fled to Greece - is decided by the Greek courts. The political condemnation of the coup does not entail that every Turkish citizen accused by Ankara of being a putschist is necessarily found to be so by the Greek courts (Kotzias Interview, 2017).

The issue also caused frictions within the Party of the Left itself and its supporters when the Syriza member of parliament Eleni Avlonitou agreed with Olga Yerovasili, the government spokesperson, and the deputy minister of national defence, Dimitris Vitsas, who had expressed their opposition to the granting of asylum to the eight. Avlonitou argued that the eight officers had been involved in crimes against humanity: 'Justice will decide but the Greek Justice cannot provide asylum to people who were shooting and bombing indiscriminately citizens by air a week ago' (ThePressProject 2016). ${ }^{6}$ The discussions on the issue caused further agitation to the supporters of Syriza who were by that time decreasing considerably in numbers, as there was a high risk of Turkey bringing back the death penalty.

Up to this point, the handling of the situation by the Greek government was based on Greek and international laws. It was for the Greek court to decide the fate of the eight. Although Tsipras often stated that coup perpetrators are not welcome in Greece, the Supreme Court of Greece rejected the extradition requests by Turkey and the asylum requests of the eight soldiers were approved in 2017. Nevertheless, the Greek government contested this decision

\footnotetext{
${ }^{6}$ Interestingly, Avlonitou's statement is nowhere to be found in the news website of the Syriza newspaper, Avgi.
} 
and filed a request for cancellation of the asylum status to the soldiers (Reuters 2017). Even though the government was clearly yielding to Turkish and potentially other pressures to extradite these soldiers, the independent justice system functioned above these diplomatic issues. As a result of the asylum case, Turkey suspended its bilateral migrant readmission deal with Greece in June 2018 (Hurriyet Daily News 2018) and Turkish Foreign Minister Çavuşoğlu stated that Turkey will keep pressuring Greece on this issue in the future (Euronews 2018)

However, some news agencies such as Worldwide Movement for Human Rights reported in May 2017 that Greece has actually returned various asylum seekers to Turkey, including a journalist, Murat Çapan, from Nokta magazine. The Hellenic League of Human Rights (HLHR) claimed that the Greek police handed Çapan over to masked men who took him back to Turkey for imprisonment. Greek authorities rejected any involvement (Worldwide Movement for Human Rights 2017). The Middle East Eye (2017) also reported a second incident in which a group of Turkish asylum seekers were deported to Turkey in the company of masked men. The Greek Ombudsman's department for Human Rights has launched an investigation into the matter, and the HLHR has filed a complaint to the Greek Supreme Court (Middle East Eye 2017). They also made the following declaration:

The refoulement to the Turkish authorities of people that are in danger of severe violations of their most basic human rights, if it has indeed taken place, is a blatant violation of international law and it is clear it was not the initiative of the local police force. We demand the immediate investigation of the incident and concrete answers from the relevant ministers concerning the policy that is in effect at the borders. The Hellenic League for Human Rights has already sent an official notice to the United Nations High Commissioner for Refugees demanding the investigation of the incident (Worldwide Movement for Human Rights 2017).

The UNHCR and the Council of Europe's Human Rights commissioner declared their concern over these allegations (Ibid).

\section{The Lausanne debate}

A few months after the putsch, the Greek government was drawn into another difficult situation, this one related to Lausanne revisionism. Since the establishment of the Turkish Republic in 1923, the Turkish elite has defined Turkey's national goals according to the needs of the Kemalist project: the creation of a new, Western-oriented nation and state, respecting the National Pact (Misak-ı Milli), which the national borders of the Republic were 
defined by the National Assembly in 1920. In that respect, the obligations arising from the Treaty of Lausanne, the final treaty concluding World War I, was signed in Lausanne, Switzerland, on 24 July 1923. The Treaty of Lausanne replaced the Treaty of Sèvres and have often been respected internationally. Furthermore, it officially settled the conflict between the Ottoman Empire and Britain, France, Italy, Japan, Greece and Romania after World War I. Furthermore, it secured the foundation of the modern Republic of Turkey after the War of Independence (1919-22).

The conflict between Ankara and Baghdad over Turkey's role in the liberation of Mosul (Iraq) had precipitated an alarming burst of Turkish irredentism, indirectly dragging Greece into the melee. Erdoğan, on two separate occasions, criticized the Treaty of Lausanne, which created the borders of modern Turkey, for leaving the country too small (Danforth 2016). On 29 September 2016, Erdoğan made a statement saying "although some tried to deceive us by presenting Lausanne as victory, in Lausanne, we gave away the islands that you could shout across to", referring to Greek islands located in the Aegean Sea close to the Turkish coastline. Furthermore, in the same speech, Erdoğan claimed that "if this coup had succeeded, they would have given us a treaty that would have made us long for Sèvres" referring to the pact that preceded the Treaty of Lausanne in 1920, abolishing the Ottoman Empire. According to Erdoğan, Turkey is still struggling with the delimitation of its continental shelf, as well as its air and land borders. Erdoğan's statements alarmed the Greek government, as well as the Greek people, whose constructed memories of the 'vicious' and 'expansionist' Turks were revived and subsequently dominated public discussions. The Greek government was again put in a difficult spot, that is how to establish a balance between public opinion and its leftist agenda.

Instantly, without being stated outright, the statements brought to the fore a number of old intercommunal issues that have yet to be resolved. These include the rights of the Greek Orthodox minority in Turkey and the pressures exerted upon minorities in general in Turkey, the state orchestrated pogrom against the Rum population in Istanbul in September 1955, and other incidents engraved in the Greek people's national identity. The Greek opposition parties tried to instrumentalise these grievances for political gain. But the Turkish president's statement received negative reactions from Turkish and international experts, as well as from the Greek government. Through its new spokesperson, Dimitris Tzanakopoulos, the Greek government responded calmly that the Greek position on this issue was in line with the international community (Naftemporiki 2017). Making a rather dangerous joke however, 
during the presentation of a book entitled Imvros-Tenedos (Gökçeada-Bozcaada in Turkish), on 3 May 2017, Foreign Minister Kotzias, referring to foreign policy issues, stated that after the Treaty of Sèvres, there was the revised Treaty of Lausanne, "Therefore, I am telling Erdoğan that if he does not like the Treaty of Lausanne, there is always the Treaty of Sèvres" (Tribune 2017). Kotzias continued however, by stating that "the Turks are used to hit at their opponents when they think they are weak", perpetuating a negative stereotype of the belligerent Turk. Such statements, coming from the institution par excellence of a country's foreign policy, and its highest representative, contribute to polarizing society, as national discourse is built on the core concepts of 'nation' and 'state'; concepts that see the other, in this case Turkey, as the 'eternal' enemy (Waever 2002).

Erdoğan's visit to Greece in early December 2017 was also remarkable with regard to reviving the discussions around Lausanne. Although the visit of a Turkish President to Greece after 65 years may seem like a positive development, the visit was not amicable throughout. Moreover, the visit, among other reasons, took place as a continuation of previous exchanges of visits between Greek and Turkish officials. On the first day of the historic visit, Erdoğan made comments regarding modernising the treaty. Greek President Prokopis Pavlopoulos responded: "The Treaty of Lausanne defines the territory and the sovereignty of Greece, and of the European Union, and this treaty is non-negotiable. It has no flaws, it does not need to be reviewed, or updated" (Tsiliopoulos 2017).

It is important to point out that internal debates clearly show that there is no consensus on the Lausanne question in Turkey's political circles. CHP's leaders also criticized Erdoğan's remarks about the treaty, as they tend to see this treaty as a victory of the Early Republic rather than a concession to foreign powers. The AKP's populist discourse regarding the 'Kemalist legacy' can instead be interpreted as a way of delegitimizing 'old Turkey's national myths' by replacing them with new ones during the creation of AKP's 'new Turkey' (Cfr Christofis 2018a). Therefore the tensions between Greece and Turkey over this issue can be seen as momentary and arose from the domestic politics of the AKP as much as from its foreign policy moves. ${ }^{7}$

However, another incident occurred just as the Lausanne issue was breaking. Turkey and Greece were forced to 'relive' an earlier bout of tension, the Imia (Turkish: Kardak) island crisis of 1996. On 21 January 2017, at that time the Turkish Chief of General Staff, Hulusi

\footnotetext{
${ }^{7}$ We thank the anonymous reviewer for pointing out these domestic nuances.
} 
$\mathrm{Akar}^{8}$, paid a visit to the island and during his visit noted that the Turkish military was an effective, dissuasive and prestigious power in the region. Immediately after his visit, media outlets in Turkey interpreted this as a threat to Greece after the issue of the eight and the Lausanne debacle. In response, some of the Greek media outlets, such as the right-wing Dimokratia declared: "The enemy is at the door" (Çandar 2017). Even though the Turkish General's behaviour was deemed benign, it had a direct link with the putsch and was a political message to Greece.

\section{Conclusion}

In this article, we discussed the impact of Turkey's political transformation on its neighbour, Greece. By specifically focusing on the Greek perspective on certain issues, we looked at how Turkey's troubles are affecting Greek-Turkish relations and what fault lines have been moved by recent developments. More theoretically speaking, it underlines that Turkey's authoritarian turn is directly affecting its foreign policy behaviours and strategies, as the constructivist school suggests. We argued that Greece is also going through a transformation under Syriza's coalition government and therefore has, at times, responded in an unorthodox manner to Turkey's actions. The two countries' bilateral relations are largely dependent on respective domestic policies, but they are also determined by and they determine the international political atmosphere as well, especially with regard to EU politics as a common ground. Further research on this topic might investigate how Turkey's transformation is affecting its diplomatic relations with other neighbours to compare the diffusion mechanisms of domestic tensions outside its borders.

This article has shown that Turkey's internal problems are spilling over to Greece via several highly visible issues such as the eight asylum seekers who were part of the coup attempt, the Lausanne debate, the brief flare-up over Imia/Kardak, as well as the incipient but growing Turkish diaspora in Greece. Recent developments have shown that the dormant tensions or so-called 'ancient hatreds' between the two countries can still affect political discourses and be brought to surface whenever deemed handy, also triggering military-security dilemmas on occasion. At the moment, these recent tensions seem to be causing only minor strains,

\footnotetext{
${ }^{8}$ Hulusi Akar is the current Turkish Minister of Defence and a former four-star Turkish Armed Forces general who served as the 29th Chief of the General Staff.
} 
considering the state of Turkish-Greek relations two decades ago. However, it can be argued that Turkey's domestic political environment; ethno-religious (Sunni Turkishness) identity shift and increasing authoritarianism is having an impact on Greece. Firstly, Greece is likely to be receiving more and more asylum or settlement applications from Turkey. Secondly, Turkey's relationship with Greece is multifaceted: at times, Turkey's actions are directed only at Greek politicians and at other times Turkey sends messages to the EU via Greece, as in the case of the EU-Turkey refugee deal. Third, Turkish, but also Greek politicians have made a habit of using nationalist rhetoric when they need to legitimate certain unpopular policy decisions. Therefore, Greece will have to adapt itself to its rapidly transforming neighbour and, while providing a bridge between the EU and Turkey, it will have to try not to be agitated by Turkish politicians' provocative remarks on issues that were thought long dead, if not buried.

\section{Notes on Contributors}

Nikos Christofis is Assistant Professor at the Center for Turkish Studies and School of History and Civilization, Shaanxi Normal University, People's Republic of China. Email: n.christofis@gmail.com Twitter: https://twitter.com/ChristofisN

Bahar Baser is an Associate Professor at Coventry University, UK, and an associate research fellow at SIGLA, Stellenbosch University, South Africa. She is currently a visiting fellow at the Kroc Institute for International Peace Studies, University of Notre Dame, USA. Email: bahar.baser@coventry.ac.uk Twitter: https://twitter.com/bahar_baser?lang=en

Ahmet Erdi Öztürk is a Swedish Institute Research Fellow at REMESO, Linköping University, Sweden. Dr. Öztürk is currently a visiting fellow at the Kroc Institute for International Peace Studies, University of Notre Dame, USA. Email:ahmeterdi.ozturk@unistra.fr Twitter: https://twitter.com/ahmeterdiozturk?lang=en

\section{References}

Akkoyunlu, K. and Öktem, K. 2016. Existential insecurity and the making of a weak authoritarian regime in Turkey. Southeast European and Black Sea Studies 16 (4): 505-527.

Aslanidis, P. and Lefkofridi, Z. 2013. "Greece: The Populist Deluge". Politix: 26-30.

'Avlonitou's 'No" for the Eight's' Officers Asylum'. 2016. ThePressProject. 21 July https://www.thepressproject.gr/article/98221/Oxi-tis-Aulonitou-gia-asulo-stous-8-Tourkous$\underline{\text { aksiomatikous }}$

Baser, B. and Korkmaz, E. Eren. 2018. "Is Turkey Really Facing an 'Exodus'? It Is Not That Simple", The Conversation, 6 February. https://theconversation.com/is-turkey-really-facingan-exodus-its-not-that-simple-90197. 
Baser, B. and Öztürk A.E. 2017. Authoritarian Politics in Turkey: Elections, Resistance and the AKP. London: I.B. Tauris.

BBC.com. 2018. Türkiye'den Meriç'i aşıp Yunanistan'a geçen göçmen sayısında büyük artış. 30 April. [Huge Increase in Migrants arriving from Turkey to Greece by Crossing Maritsa] https://www.bbc.com/turkce/haberler-dunya-43948284

Benhabib, S. 2017. Turkey is about to take another step toward dictatorship. The Washington Post, $16 \quad$ March. $\quad$ https://www.washingtonpost.com/news/democracypost/wp/2017/03/16/turkey-is-about-to-take-another-step-towarddictatorship/?utm_term=.479f9b29402c.

Bialasiewicz, L. and Maessen, E. 2018. Scaling rights: the 'Turkey deal' and the divided geographies of European responsibility. Patterns of Prejudice 52 (2-3): 210-230.

Bilgic, A. and Pace, M. 2017. The European Union and refugees. A struggle over the fate of Europe. Global Affairs 3 (1): 89-97.

Çandar, C. 2017. Why Turkey-Greece islands confrontation is more than it seems. Al Monitor, $\quad 1 \quad$ February. $\quad$ http://www.almonitor.com/pulse/tr/contents/articles/originals/2017/01/turkey-greece-european-unionisland-crisis.html

Çarkoğlu, A. and Kirişçi, K. 2004. The View from Turkey: Perceptions of Greeks and Greek-Turkish Rapprochement by the Turkish Public. Turkish Studies 5 (1): 117-153.

Christofis, N. 2014. SYRIZA'nın Tarihi Seçim Zaferi ve Anlamı [SYRIZA's Historical Election Victory and Its Meaning]. EkoAvrasya 27 (3): 48-49.

Christofis, N. 2018a. The AKP's 'Yeni Türkiye': Challenging the Kemalist Narrative? Mediterranean Quarterly: A Journal of Global Issues 23 (3): 11-32.

Christofis, N. 2018b. Turkey, Cyprus, and the Arab Uprisings. In H. Iş1ksal and O. Göksel, eds. Turkey's Relations with the Middle East: Political Encounters after the Arab Spring: 133-150. Cham, Switzerland: Springer.

Christofis, N., and L. Amaryllis. 2018. Turkey in Syriza's Foreign Policy, 2015-2017. In The Role of the Image in the Greek-Turkish Relations, edited by Z. M. Uzuner: 103-120. Frankfurt am Main: Peter Lang.

Chrysopoulos, P. 2015. Greek Foreign Minister: Jihadists will Flock in Europe if Greece Crumbles. Greek Reporter. 7 March, https://greece.greekreporter.com/2015/03/07/greekforeign-minister-jihadists-will-flock-in-europe-if-greece-crumbles/

Çınar, M. 2018. From Moderation to De-Moderation: Democratic Backsliding of the AKP in Turkey. In J. L. Esposito et al. eds. The Politics of Islamism: Diverging Visions and Trajectories: 127-157. London: Palgrave Macmillan.

Couloumbis, T. A. and Kentikelenis, A. E. 2007. Greek-Turkish relations and the Kantian democratic peace theory. Southeast European and Black Sea Studies 7 (4): 517-532. 
Daily Sabah. 2016. Coup soldiers fled to Greece being brought back to Turkey, 17 July, https://www.dailysabah.com/diplomacy/2016/07/17/coup-soldiers-fled-to-greece-being-

brought-back-to-turkey

Danforth, N. 2016. Turkey's New Maps Are Reclaiming the Ottoman Empire. Foreign Policy, 23 October. http://foreignpolicy.com/2016/10/23/turkeys-religious-nationalists-wantottoman-borders-iraq-Erdoğan/.

"Demirtaş at the $2^{\text {nd }}$ Congress: Let's Build Together a Front of Resistance against Fascism and Exploitation", 2016a. Left.gr 13 October https://left.gr/news/s-ntermitas-sto-2osynedriooikodomisoyme-mazi-ena-metopo-antistasis-enantia-sto-fasismo-kai-tin

DW.com. 2018. Türkiye'den Almanya'ya İrtica Başvuruları Arttı. 3 October. [Asylum Applications From Turkey Skyrocket in Germany] https://www.dw.com/tr/t\%C3\%BCrkiyeden-almanyaya-iltica-ba\%C5\%9Fvurular\%C4\%B1$\underline{\operatorname{artt} \% \mathrm{C} 4 \% \mathrm{~B} 1 / \mathrm{a}-45738461}$

Emmott, R. and Koutantou, A. 2017. Greece blocks EU statement on China human rights at U.N. Reuters, 18 June. https://www.reuters.com/article/us-eu-un-rights/greece-blocks-eustatement-on-china-human-rights-at-u-n-idUSKBN1990FP

Esen, B. and Gumuscu, S. 2016. Rising Competitive Authoritarianism in Turkey. Third World Quarterly 37 (9): 1581-1606.

Euronews. 2018. Türkiye Yunanistan'la geri kabul anlaşmasını durdurdu. 7 June. [Turkey Suspends Migrant Readmission Deal with Greece] https://tr.euronews.com/2018/06/07/turkiye-yunanistan-geri-kabul-anlasmasini-durdurdu

European Council. 2016. EU-Turkey statement. 18 March. https://www.consilium.europa.eu/en/press/press-releases/2016/03/18/eu-turkey-statement/

Grekodom.com. 2017. BoG Data Reveals Increase in Turks Buying Greek Properties. 17 January. $\quad$ https://www.grekodom.com/news/2017-01-18/bog-data-reveals-increase-in-turks$\underline{\text { buying-greek-properties }}$

Heraclides, A. 2012. 'What will become of us without barbarians?' The enduring GreekTurkish rivalry as an identity-based conflict. Southeast European and Black Sea Studies 12 (1): 115-134.

Heraclides, A. 2017. The talks on the solution of the Cyprus problem at the crossroads. Chronos. 47. 8 March https://chronos.fairead.net/irakleidis-staurodromi

Hurriyet Daily News. 2018. "Turkey suspends 'migrant readmission' deal with Greece" 7 June http://www.hurriyetdailynews.com/turkey-suspends-refugee-readmission-deal-withgreece-132955 
Immigration.ca n.d. Turkish Investors Flock to Greece Golden Visa. https://www.immigration.ca/turkish-investors-flock-greece-golden-visa

Insel, A. 2003. The AKP and normalizing democracy in Turkey. The South Atlantic Quarterly 102 (2): 293-308.

Karakatsanis, L. 2014. Turkish-Greek Relations: Rapprochment, Civil Society and the Politics of Friendship. London and New York: Routledge.

Karakatsanis, L. 2017. Another "first time after all these years"? About Erdoğan's Visit. Synchrona Themata 138/139: 10-12.

Ker-Lindsey, J. 2007. Greek-Turkish Rapprochement under New Democracy. The International Spectator 42(2): 237-247

Kitsantonis, N. and Gall, G. 2017. Erdoğan, on Landmark Visit to Greece, Sets Diplomacy Aside. The New York Times, 7 December. https://www.nytimes.com/2017/12/07/world/europe/erdogan-greece-turkey-visit.html

Konstandaras, N. 2016. Turkey's Turmoil and its Ties with Greece. Ekathimerini, 21 July. http://www.ekathimerini.com/210654/opinion/ekathimerini/comment/turkeys-turmoil-andits-ties-with-greece.

'Kotzias Deconstructed Turkey: Turkey Should Give the Kurds the Rights it asks for the Turkish Cypriots'. 2017. HellasJournal 11 June. http://mignatiou.com/2017/06/apodomisetin-tourkia-o-kotzias-na-dosi-stous-kourdous-ta-dikeomata-pou-zita-gia-tous-tourkokiprious/

'Kotzias Interview'. 2017. SKAI TV. 21 February. http://www.mfa.gr/cyprus/en/theembassy/news/foreign-minister-kotzias-interview-with-alexis-papahelas-on-skai-tvs-istoriestuesday-21-february-2017.html

'Kotzias to Erdoğan: If you don't like the Lausanne Treaty there is also the Treaty of Sevres'. 2017. Tribune. 4 May https://www.tribune.gr/politics/news/article/356063/kotzias-proserntogan-ean-den-sou-aresi-synthiki-tis-lozanis-yparchi-ke-synthiki-ton-sevron.html

Larrabee, F. S. 2012. Greek-Turkish relations in an era of regional and global change. Southeast European and Black Sea Studies 12 (4): 471-479.

Mazower, M. 2015. European Democracy Enters Dangerous Times. Financial Times, 30 January. 00144feab7de.html\#axzz3h2QIRd6i

http://www.ft.com/intl/cms/s/0/aeab01f2-a70b-11e4-8a71-

Michalopoulos, S. 2015. Tsipras: Greece is a part of Europe. euractiv.com, 27 June. https://www.euractiv.com/section/euro-finance/news/tsipras-greece-is-part-of-europe/

Middle East Eye. 2017. Greece accused of forcing Turkish asylum seekers back home. 22 June, http://www.middleeasteye.net/news/greece-pushing-back-turkish-asylum-seekershands-Erdoğan-125495992 
Milan, F.F., 2016. "Turkey: What hides behind a failed coup attempt." The RUSI Journal 161(4): 28-32.

Migrantsrights.org. 2018. Home Office scraps right to remain provisions for Turkish nationals on business visas. 24 April. https://migrantsrights.org.uk/blog/2018/04/24/homeoffice-scraps-right-to-remain-provisions-for-turkish-nationals-on-business-visas/

Neuger, J. G., and Chrepa, E. 2015. Syriza Massages Foreign Policy Goals as it Smells Power. Bloomberg Business. http://www.bloomberg.com/news/articles/2015-01-14/syrizamassages-foreign-policy-goals-as-it-smells-power

"No to the Dictatorship of Erdoğan": Massive Demonstration of Solidarity to HDP', 2016c. Left.gr, 5 November https://left.gr/news/freehdpnow-se-sygkentrosi-sto-syntagma-mesimeritoy-savvatoy-kalei-politistiko-kentro.

Norris, P. 2005. Radical Right: Voters and Parties in the Electoral Market. Cambridge: Cambridge University Press.

O'Connor, F. and Baser, B. 2018. Communal violence and ethnic polarization. Southeast European and Black Sea Studies 18(1), 53-72.

Ovenden, K. 2015. Syriza: Inside the Labyrinth. London: Pluto Press.

Özbudun, E. 2014. AKP at the crossroads: Erdoğan's Majoritarian Drift. South European Society and Politics 19 (2): 155-167.

Öztürk, A. E., Gözaydın, İ. 2017. Turkey's constitutional amendments: a critical perspective. Research and Policy on Turkey 2(2):210-224.

Petsinis, V. 2017. Syriza and Anel: a match made in Greece. Opendemocracy, 25 January. https://www.opendemocracy.net/can-europe-make-it/vassilis-petsinis/syriza-and-ANELmatch-made-in-greece

'Presence of Syriza in the Historic Meeting of HDP in Izmir', 2015, Avgi, 25 May http://www.avgi.gr/article/5566358/parousia-tou-suriza-stin-istoriki-sugkentrosi-tou-hdp-stismurni.

Raptopoulos, N. 2017. Greek-Turkish Relations during the Greek Crisis: The Impact of the Crisis on Partnership Efforts. In N. Litsas and A. S. Tziampiris, eds. Foreign Policy under Austerity: Greece's Return to Normality?: 117-140. London: Palgrave Macmillan.

Reuters. 2017. Greek government files request to cancel Turkish soldier's asylum. The Guardian, 30 December. https://www.theguardian.com/world/2017/dec/30/greekgovernment-files-request-to-cancel-turkish-soldiers-asylum

Roussanoglou, N. 2017. More and More Turks Buying Greek Property. Ekathimerini, 15 January. http://www.ekathimerini.com/215306/article/ekathimerini/business/more-and-moreturks-buying-greek-property. 
Shaheen, K. and Lyons, K. 2018. Turkey Election. The Guardian, 25 June. https://www.theguardian.com/world/2018/jun/24/erdogan-claims-victory-in-turkishpresidential-election

Spourdalakis, M. 2016. Rekindling Hope: Syriza's Challenges and Prospects. Socialist Project. 27 January. http://socialistproject.ca/bullet/1213.php

Sputniknews.com. 2018. Türkiye'den Yunanistan'a İltica Başvurusu 5 Bin 786'ya Çıktı [5.786 Turkish Nationals Seek Asylum in Greece]. 11 December. https://tr.sputniknews.com/turkiye/201811111036093554-turkiye-yunanistan-iltica-basvuru/.

Strickland, P. 2018. Greece: FM Kotzias resigns amid tensions over Macedonia accord. Al Jazeera, 17 October. https://www.aljazeera.com/news/2018/10/greece-fm-kotzias-resignstensions-macedonia-accord-181017143057917.html

Synaspismos. 2009. Greece in the World. 15 February http://www.syn.gr/gr/keimeno.php?id=14088.

"Syriza Expresses its Solidarity to the Turkish People". 2013. NewsBeast, 6 February. http://www.newsbeast.gr/politiki/arthro/539704/allileggui-ston-tourkiko-lao-ekfrazei-o-suriza

Syriza, 2015. "Positions on Foreign Policy". January https://www.syriza.gr/theseis/pros_diavoulefsi_exoteriki_politiki.pdf

Tekdemir, O. 2016. Conflict and reconciliation between Turks and Kurds: the HDP as an agonistic actor. Southeast European and Black Sea Studies 16 (4): 651-669.

Tezcür, G. M., and A. Grigorescu. 2014. Activism in Turkish Foreign Policy: Balancing European and Regional Interests. International Studies Perspectives 15 (3): 257-276.

"The Kurdish and Refugee Issues at the Center of the Tsipras-Demirtas Meeting", 2016b. Left.gr. 15 February. https://left.gr/news/koyrdiko-kai-prosfygiko-sto-epikentro-tis$\underline{\text { synantisis-tsipra-ntemirtas }}$

Tisdall, S. 2018. Recep Tayyip Erdoğan. The Guardian, 19 April. https://www.theguardian.com/world/2018/apr/19/recep-tayyip-erdogan-turkey-presidentelection-dictator-seeks-total-control

Triantaphyllou, D. 2017. Greek-Turkish relations and the perceptions of their elites. LSE Greece@ LSE. Blog. http://blogs.lse.ac.uk/greeceatlse/2017/01/31/greek-turkish-relationsand-the-perceptions-of-their-elites/

'Tsipras' Speech'. 2014. http://www.syriza.gr/article/id/57965/OMILIA-TOY-PROEDROYTOY-SYRIZA-ALEKSH-TSIPRA-STO-SYNEDRIAKO-KENTRO-I.-BELLIDHSThESSALONIKH-13-9-2014.html\%23.WMgruPmLS02.

Tsitsopoulos, C. "Turkey's lost "8" and the era of ambiguity in Greek-Turkish Affairs", Independent Turkey, 19 December 2016. Accessed 25 July 2017. http://independentturkey.org/turkeys-lost-8-era-ambiguity-greek-turkish-affairs/. 
Tsiliopoulos. E. 2017. How global media reacted to the Turkish President's visit to Greece. New Greek, 8 December. http://www.newgreektv.com/english-news/item/23913-how-globalmedia-reacted-to-the-turkish-president-s-visit-to-greece

'Tzanakopoulos: The Lausanne Treaty is not Negotiable'. 2017. Naftemporiki. 6 December https://www.naftemporiki.gr/story/1302154/d-tzanakopoulos-adiapragmateutos-o-sebasmossti-sunthiki-tis-lozanis

Tziampiris, A. 2017. Foreign Policy against Austerity: Syriza's Multifaceted Experiment. In N. Litsas and A. S. Tziampiris, eds. Foreign Policy under Austerity: Greece's Return to Normality: 261-292. London: Palgrave Macmillan.

Tziampiris, A. 2016. Greece after Turkey's Coup D'état. Huffington Post. 22 July. http://www.huffingtonpost.com/aristotle-tziampiris/greece-after-turkeyscoup_b_11110934.html.

Wæver, O. 2002. Identities, communities and foreign policy: discourse analysis as foreign policy theory. In L. Hansen and O. Wæver, eds. European Integration and National Identity: The Challenge of the Nordic States: 20-49. London: Routledge.

Walker, S. 2015. Alexis Tsipras in Moscow asks Europe to end sanctions against Russia. The Guardian, 8 April. https://www.theguardian.com/world/2015/apr/08/alexis-tsipras-inmoscow-asks-europe-to-end-sanctions-against-russia

Watmough, S. P. and Öztürk, A. E. 2018. From 'Diaspora by Design' to Transnational Political Exile: The Gülen Movement in Transition. Politics, Religion \& Ideology 19 (1): 3352.

Weise, Z. 2018. Erdoğan's enemies find sanctuary close to home. politico.eu, 14 March. https://www.politico.eu/article/turkey-erdogan-enemies-find-sanctuary-in-greece-asylum/

Worldwide Movement for Human Rights. 2017. Turkish journalist imprisoned in Turkey after refoulement from Greece with other asylum seekers. 30 May. https://www.fidh.org/en/issues/migrants-rights/turkish-journalist-imprisoned-in-turkey-afterrefoulement-from-greece 